\title{
Techniques d'équitation et antagonismes sociaux.
}

A propos de trois ouvrages récents

Jean-Pierre Digard

\section{OpenEdition}

Journals

Édition électronique

URL : https://journals.openedition.org/tc/1016

DOI : $10.4000 /$ tc. 1016

ISSN : 1952-420X

Éditeur

Éditions de l'EHESS

Édition imprimée

Date de publication : 1 juin 1984

ISSN : 0248-6016

Référence électronique

Jean-Pierre Digard, «Techniques d'équitation et antagonismes sociaux. », Techniques \& Culture [En ligne], 3 | 1984, mis en ligne le 26 janvier 2006, consulté le 29 septembre 2022. URL : http://

journals.openedition.org/tc/1016; DOI : https://doi.org/10.4000/tc.1016

Ce document a été généré automatiquement le 29 septembre 2022.

Tous droits réservés 


\section{Techniques d'équitation et antagonismes sociaux.}

A propos de trois ouvrages récents

Jean-Pierre Digard 